\title{
MECHANICS AND MATHEMATICAL MODELING OF CLASS III TREATMENT WITH ORTHODONTIC APPLIANCES WITH A MOVABLE RAMP
}

\author{
Petro Flis \\ Department of Orthodontics and Prosthodontics Propedeutics \\ O. O. Bogomolets National Medical University \\ 13 Shevchenko blvd., Kyiv, Ukraine, 01601 \\ Alexander Grigorenko \\ Department of computation methods \\ S. P. Timoshenko Institute of Mechanics \\ 3 Nesterova str., Kyiv, Ukraine, 03057 \\ Nataliia Doroshenko \\ Department of Orthodontics and Prosthodontics Propedeutics \\ O. O. Bogomolets National Medical University \\ 13 Shevchenko blvd., Kyiv, Ukraine, 01601 \\ Mykola Tormakhov \\ Department of computation methods \\ S. P. Timoshenko Institute of Mechanics \\ 3 Nesterova str., Kyiv, Ukraine, 03057 \\ Valeriy Filonenko \\ Department of Orthodontics and Prosthodontics Propedeutics \\ O. O. Bogomolets National Medical University \\ 13 Shevchenko blvd., Kyiv, Ukraine, 01601
}

\begin{abstract}
Treatment of Class III is a current problem in orthodontics that requires constant improvement of its methods, development of new or modifications of known methods and techniques. We have developed and studied the modification of removable functionally-directing orthodontic appliances for treatment of Class III, which consists of a plastic base, vestibular arc, retaining clasps, ramp, which is connected with the base by means of two torsion springs. Its usage ensures a prolonged contact of ramp with the teeth.

We studied two types of club-shaped springs (torsion springs): one spring, which create an amortization effect during the action of the ramp, but do not change its inclination angle and second one - spring that seek to increase the angle of the ramp inclination due to the disclosure of its curl.

Keywords: orthodontic forces, movable ramp, club-shaped springs, rigidity of orthodontic appliances.

\section{Introduction}

The aim of our study: improvement of functionally-directing orthodontic appliances for improving the efficiency of Class III treatment.

For orthodontic abnormalities treatment orthodontic appliances are used. They must create the orthodontic force with necessary magnitude and direction and act during certain period of time. The source of force in functionally-directing appliances is the masticatory muscles contractile force at the moment of contact of teeth or alveolar crest with the ramp or occlusal plane, bite ramps etc. Orthodontic forces in functional devices acts intermittently and dosage quantities of these forces are done by the patient, who is guided by his pain reception [1-4].

The disadvantages of known orthodontic appliances with ramp should include the difficulty for the patient to maintain the necessary level of orthodontic forces and insufficient duration of their action [1-5].
\end{abstract}


The maximum contact between the dental arches is observed during swallowing. Without orthodontic appliance in the mouth it's a central occlusion. With an orthodontic appliance in the mouth - it's contact of a group of teeth with ramp. Most of the time during the day dentoalveolar apparatus is in a state of relative physiological rest $[2,6]$.

The average amount of saliva swallowing per day is: 1200-1300 times (55-60 h) (Kydd and Neff, 1964; Gibbs et al., 1981), 600 times (200 times, including during the meal, 50 - in sleep time, $350-$ at any other time) (Henderson, 2013) [7]. Swallowing time - 0,2-0,5s. Due to this data, maximum contact of tooth occlusion surfaces lasts for 8-20 min. during the day (Lear et al., 1965, Sheppard and Markus, 1962) [1,8].

\section{Aim}

Mechanical and mathematical modeling of orthodontic appliance with a movable ramp action for improvement of malocclusion treatment methods.

\section{Materials and methods}

We invented an orthodontic appliance (declarative patent of Ukraine № 99388 from 25.05.2015), which consists of a plastic base, vestibular arc, retaining clasps, ramp, which is connected with the base by means of two torsion springs (Fig. 1) [9-11]. Its usage ensures a prolonged contact of ramp with the teeth.

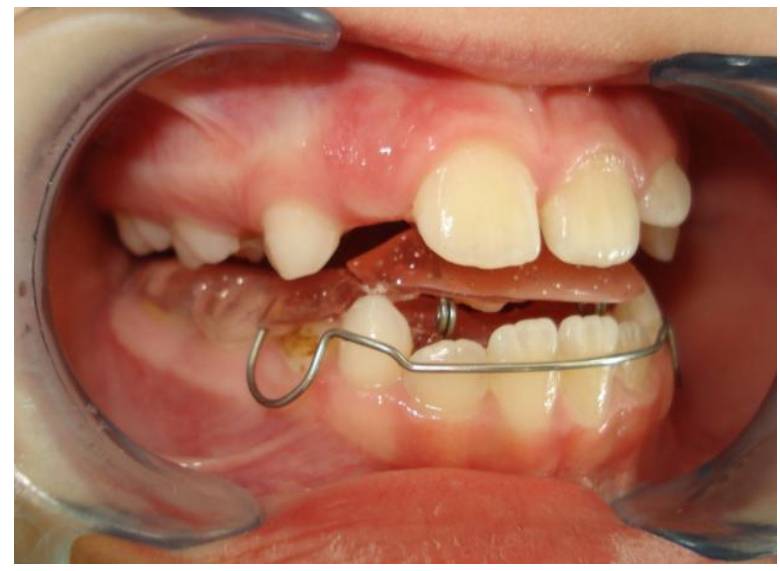

Fig. 1. An orthodontic appliance with a movable ramp in the mouth

The object of our study is a system which consists of dentoalveolar apparatus and orthodontic appliance with a movable ramp, which is designed for orthodontic treatment.

The parameters used in this studies are: the angle of appliance's ramp, the size of the facial skeleton (the distance from the point that corresponds to the center of the head of the temporomandibular joint to the contact point of the central incisors), the angle of axial inclination of the anterior teeth, the coefficient of friction between the ramp and the patient's teeth. Two types of club-shaped springs (torsion springs) was studied: 1 - spring which create an amortization effect during the action of the ramp, but do not change its inclination angle (passive); 2 - spring that seek to increase the angle of inclination of the ramp due to the disclosure of its curl (active).

We divided mechanical modeling of Class III treatment process for research of forces that occur in the dentoalveloar apparatus and for study the process of orthodontic forces changing. Investigation of changes in orthodontic forces we carried out by studying their changes during vertical and sagittal displacements of the ramp relative to the upper teeth. Tasks were solved using classical methods of theoretical mechanics [6, 12-17].

The study suggested that resizing of all parts of the dentoalveloar apparatus, apart from movable ramp inclination changing by torsion springs, is low and this changes can be neglected, we assume the hypothesis of friction absence in the temporomandibular joints [18-20]. 
The development of designing methods of orthodontic appliance with a movable ramp was held within the materials resistance, which is a branch of mechanics of deformable solids science [21-23]. In calculations of the basic parameters of torsion springs, they regarded as the curveshape spiral rod that works on a bend. Stress-strain state of torsion springs was determined by the hypothesis of continuity, homogeneity and isotropy, which are built by the mechanics of deformable solids science.

\section{Experimental procedures}

During the Class III treatment an appliance 1 with a movable ramp 2 is placed on the lower dental arch 3 (Fig. 2). The upper and lower jaw are connected by temporomandibular joint with disc 4 and masseteric, temporal, medial and lateral pterygoid muscles, which provide jaws force contact.

The resultant of all the forces, which are generated by these muscles, is shown in the vector $\mathrm{K}_{\mathrm{M}}$. The upper and lower jaw with the temporomandibular joints and muscles constitute a mechanism that converts force $\mathrm{K}_{\mathrm{M}}$ to the mastication forces, and the appliance 1 - in orthodontic force $\mathrm{R}_{1}$, which is leading to the teeth and alveolar crest displacement by restructuring the bone. The patient's bite is corrected in such way.

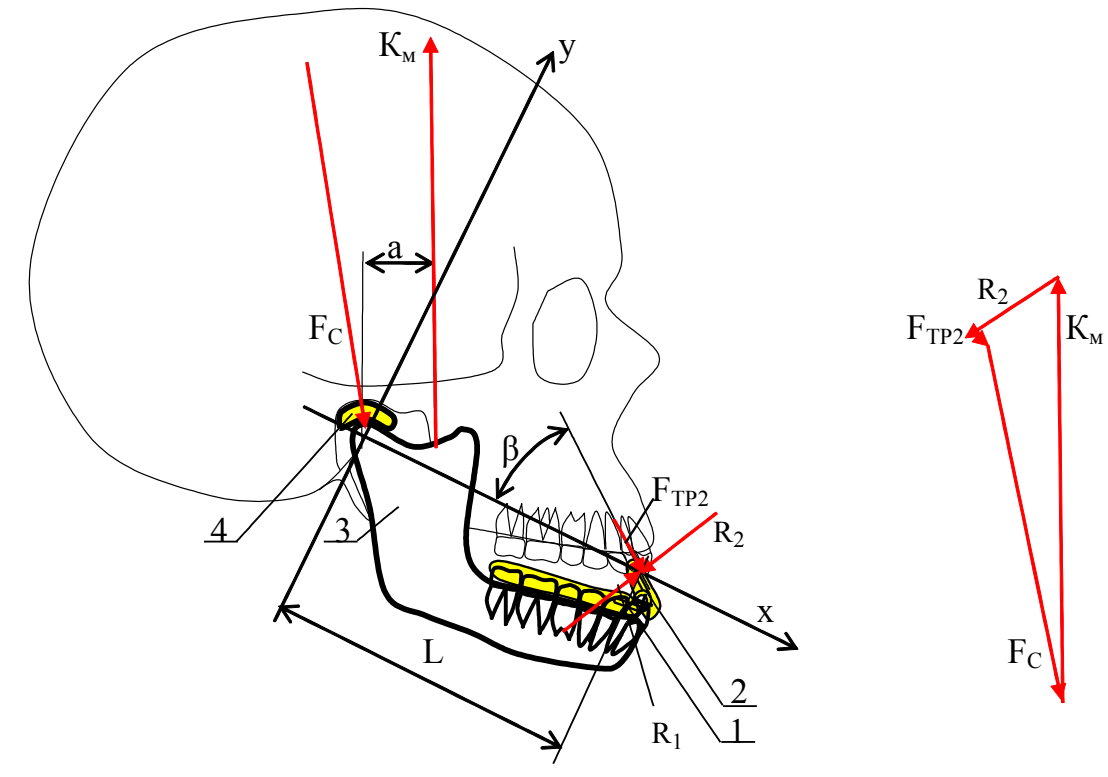

Fig. 2. Forces in the dentoalveolar apparatus during theClass III treatment by means of orthodontic appliance with a movable ramp

The force $\mathrm{R}_{1}$ is applied to the cutting edge of the frontal teeth of the upper jaw and has vestibular direction. $R_{1}$ force causes the reaction force $R_{2}$, which is equal to the force $R_{1}$ but acts through the ramp of the lower jaw in the opposite direction [21]. Apart from $\mathrm{R}_{1}$ and $\mathrm{R}_{2}$ forces, two friction forces $\mathrm{F}_{\mathrm{TP} 1}, \mathrm{~F}_{\mathrm{TP} 2}$ are arising at the contact point of the frontal teeth of the upper jaw and ramp. They prevent mutual sliding between the ramp and the teeth. Force $\mathrm{F}_{\mathrm{TP} 1}$ (at Fig. 2 is not shown) acts on the upper jaw, force $\mathrm{F}_{\mathrm{TP} 2}$ is equal but oppositely directed to the $\mathrm{F}_{\mathrm{TP} 1}$ and acts on the lower jaw through the ramp. Frictional forces are [21]:

$$
\mathrm{F}_{\mathrm{TP} 1}=\mathrm{kR}_{1}, \mathrm{~F}_{\mathrm{TP} 2}=\mathrm{kR}_{2}
$$

where $\mathrm{k}$ - is the friction coefficient.

Since the lower jaw is in the equilibrium state because of the action of forces applied to it, the algebraic sum of the forces moments acting on it is zero [21]. If we neglect the weight of the lower jaw and friction in the temporomandibular joint, which is amortized by synovial fluid, then the lower jaw will get forces $\mathrm{K}_{\mathrm{M}}, \mathrm{R}_{2}, \mathrm{~F}_{\mathrm{TP} 2}$ and the force $\mathrm{F}_{\mathrm{C}}$ from the temporomandibular joint. 
We place a Cartesian coordinate system in such a way that the origin is in the center of the temporomandibular joint and the $\mathrm{x}$ axis passes through the contact point of the frontal teeth of the upper jaw with ramp 2. The equation of the moments of the forces acting on the lower jaw relative to the center of the articular tubercle has the form [21]:

$$
\mathrm{K}_{\mathrm{M}} \mathrm{a}-\mathrm{R}_{2} \mathrm{~L} \cos \beta-\mathrm{F}_{\mathrm{TP} 2} \mathrm{~L} \sin \beta=0,
$$

where $\mathrm{a}-$ is the distance from the center of the temporomandibular joint rotation to vector $\mathrm{K}_{\mathrm{M}}$, $\mathrm{L}$ - is coordinate of the point of the upper frontal teeth cutting edge, $\beta$ - is the angle between the ramp and the $\mathrm{x}$ axis.

Solving the equation (2) due to $\mathrm{R}_{2}$ with regard to (1) we obtain:

$$
\mathrm{R}_{2}=\mathrm{aK}_{\mathrm{M}} /[\mathrm{L}(\cos \beta+\mathrm{k} \sin \beta)] .
$$

Eq. (3) shows that orthodontic force $\mathrm{R}_{2}$ depends on the facial skeleton size a and $\mathrm{L}, \mathrm{K}_{\mathrm{M}}$ muscle force, friction coefficient $\mathrm{k}$ and the angle $\beta$ between the ramp and the $\mathrm{x}$-axis.

$$
\beta=\operatorname{arctgk}
$$

Orthodontic force $\mathrm{R}_{2}$ can be decomposed into: the force acting along the tooth axis $\mathrm{Q}$, and the force $\mathrm{P}$ which is directed in a perpendicular direction to this axis (Fig. 3):

$$
\begin{aligned}
& \mathrm{P}=\mathrm{R}_{2} \cos (\alpha-\beta), \\
& \mathrm{Q}=\mathrm{R}_{2} \sin (\alpha-\beta),
\end{aligned}
$$

where $\alpha$-is the inclination angle of the tooth axis relative to the $\mathrm{x}$ axis.

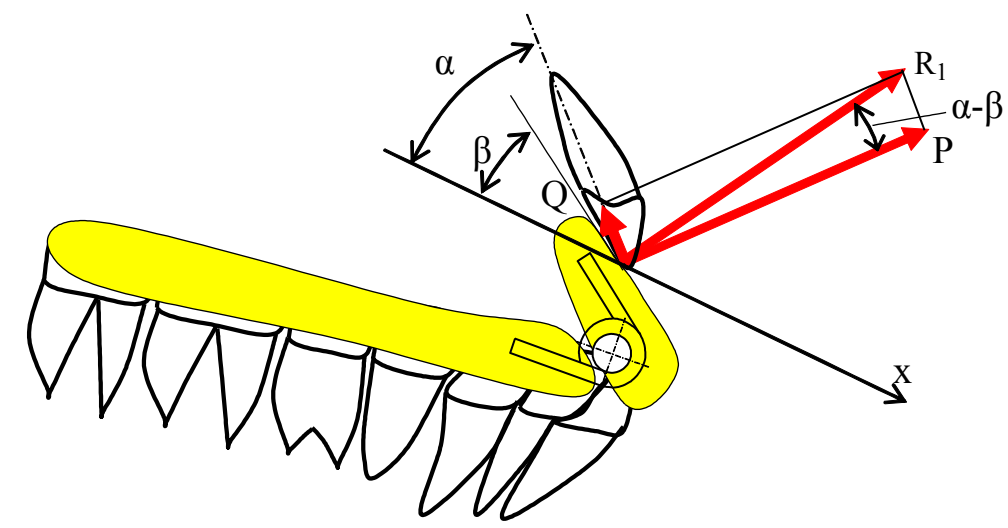

Fig. 3. The components $\mathrm{Q}$ and $\mathrm{P}$ of orthodontic force $\mathrm{R}_{1}$ in the treatment of Class III

Substituting (3) into (5) we obtain the following expression for the forces P and Q:

$$
\begin{aligned}
& \mathrm{P}=\mathrm{a} \mathrm{K}_{\mathrm{M}} \cos (\alpha-\beta) /[\mathrm{L}(\cos \beta+\mathrm{k} \sin \beta)], \\
& \mathrm{Q}=\mathrm{a} K_{\mathrm{M}} \sin (\alpha-\beta) /[\mathrm{L}(\cos \beta+\mathrm{k} \sin \beta)] .
\end{aligned}
$$

The force Q progressively moves the frontal teeth in the axial direction, and the force $\mathrm{P}$ - in the vestibular direction with translational-rotational move. We can change the forces $\mathrm{P}$ and $\mathrm{Q}$ by setting different angles of ramp inclination $\beta$. The angle of the axis inclination of the tooth $\alpha$ at the beginning of treatment is determined by the anatomical characteristics of the patient and can be in the range $45-75^{\circ}$. Since the orthodontic force vector is directed labially, the angle $\beta$ is 
in the range from $-30^{\circ}$ to $\alpha$. The forces $\mathrm{P}$ and $\mathrm{Q}$ are calculated using the formula (6) for force $\mathrm{K}_{\mathrm{M}}=-10 \mathrm{~N}$ and the ratio $\mathrm{a} / \mathrm{L}=0,23$, angles $\beta$, equal to $-30^{\circ},-15^{\circ}, 0^{\circ}, 15^{\circ}, 30^{\circ}$ and angle $\alpha$, equal to $45^{\circ}, 60^{\circ}, 75^{\circ}$ (Table 1 ).

Based on the orthodontic forces calculations the force P increases and force Q decreases with increasing of angle $\beta$. The angle between the ramp and the frontal teeth axis $(\alpha-\beta)$ influences the ratio between the forces $\mathrm{P}$ and $\mathrm{Q}$. When $(\alpha-\beta)<45^{\circ}$ - force P exceeds $\mathrm{Q}$, if $(\alpha-\beta)=45^{\circ}$, then $\mathrm{F}=\mathrm{Q}$, and when $(\alpha-\beta)>45^{\circ}-$ force $\mathrm{P}$ ratio will be less than $\mathrm{Q}$. Forces $\mathrm{P}<\mathrm{Q}$ is not desirable, since the inclination of the tooth must prevail over its intrusion. Most preferred angle between the ramp and the frontal teeth axis $(\alpha-\beta)$ is about $30^{\circ}$.

Table 1

Dependence of forces $\mathrm{P}$ and $\mathrm{Q}$ on the angles $\alpha$ and $\beta$

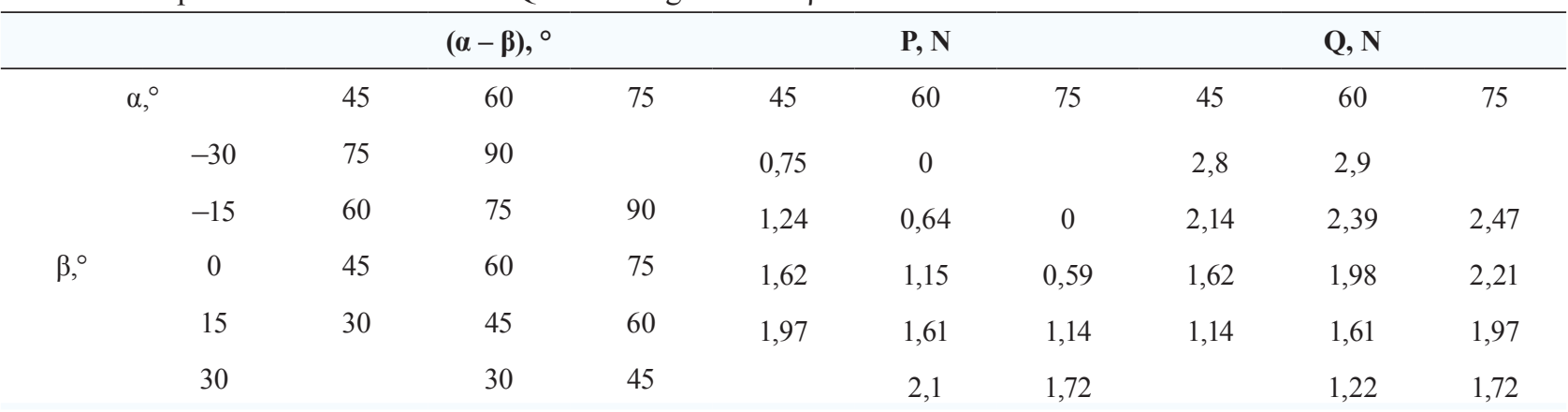

Club-shaped springs of orthodontic appliance (Fig. 4) act as elastic hinges, which reduce its rigidity. The main parameters of the springs are: wire diameter (d), the outer diameter (D) and the number of curves (n). The free ends of the springs are fixed in the plastic base and the ramp. The angle between the free ends of the springs is $\gamma$.
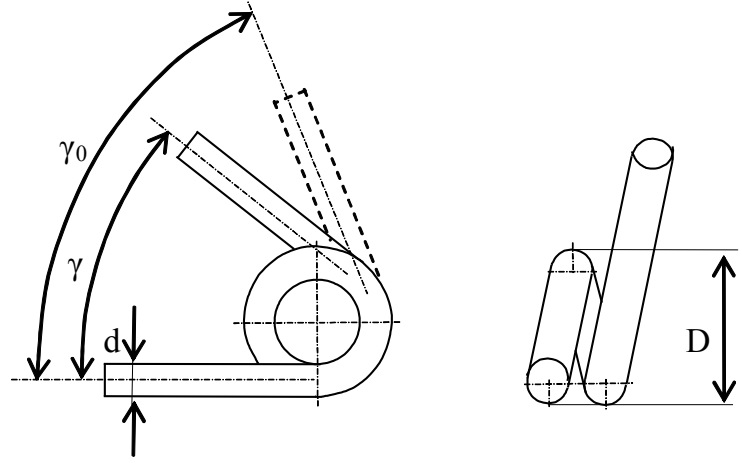

Fig. 4. The torsion spring of orthodontic appliance

Spring is made of wire with a diameter from 0.4 to $0.8 \mathrm{~mm}$ when the outer diameter of $2 \mathrm{~mm}$. The free ends of the spring are loaded with the force of $R_{2}$, which is reaction force of the upper frontal teeth and equal to the orthodontic force $\mathrm{R}_{1}$ but has opposite direction. The force $\mathrm{R}_{2}$ generates a torque in relation to the spring axis [6]:

$$
\mathrm{M}=\mathrm{R}_{2} 1
$$

where 1 - distance from the line of action of force $\mathrm{R}_{2}$ to the spring axis (moment arm).

Torque $\mathrm{M}$ varies with the angle $\gamma$ (between the free ends of the spring). In the unloaded state when the moment $\mathrm{M}=0$, the angle between the free ends of the spring becomes equal to $\gamma_{0}$. The relationship between torque $\mathrm{M}$ and the angle $\gamma$ is described by the equation: 


$$
\mathrm{M}=\zeta \gamma+\mathrm{M}_{0}
$$

where $\zeta$ - is the coefficient of springs rigidity in torsion, $\mathrm{M}_{0}-$ is the coefficient, which is equal to the torsion moment at $\gamma=0$.

The coefficient $\zeta$ describes the stiffness of the spring in torsion [7]:

$$
\zeta=\pi \mathrm{E}_{\mathrm{C}} \mathrm{d}^{4} /\left(1,152 \cdot 10^{3} \mathrm{nD}\right)
$$

where $\mathrm{E}_{\mathrm{C}}=2 \cdot 10^{5} \mathrm{MPa}-$ modulus of elasticity of steel.

Stiffness of the appliance we can calculate by substituting in (9) various data of wire diameter $(\mathrm{d}=0.4 \ldots 0.8 \mathrm{~mm}$.$) and the number of spring curves (\mathrm{n}=1 \ldots .5)$.

The more stable and the longer is maintained by the required level of orthodontic force, the more efficient is the process of orthodontic treatment.

Exploring the dynamics of orthodontic force action during vertical movements of the lower jaw was found out that its maximum value is observed at the moment of swallowing, when the jaws have maximum contact. In moments of rest occlusal surface of upper and lower teeth are alienated by a distance $\lambda=2 \ldots 4 \mathrm{~mm}$, which reduces the orthodontic force (Fig. 5, $\boldsymbol{a}$ ). If at the time of maximum teeth contact the angle between the teeth and the ramp of appliance was equal $\gamma_{\mathrm{C}}$, after divergence of the jaws by a distance $\lambda($ Fig. $\mathbf{5}, \boldsymbol{b})$ this angle becomes equal to:

$$
\gamma=\operatorname{arctg}\left[\left(1_{C} \sin \gamma_{C}+\lambda\right) /\left(1_{C} \cos \gamma_{C}\right)\right]
$$

where $\mathrm{l}_{\mathrm{C}}-$ moment arm of $\mathrm{R}_{2}$ during jaws max contact.

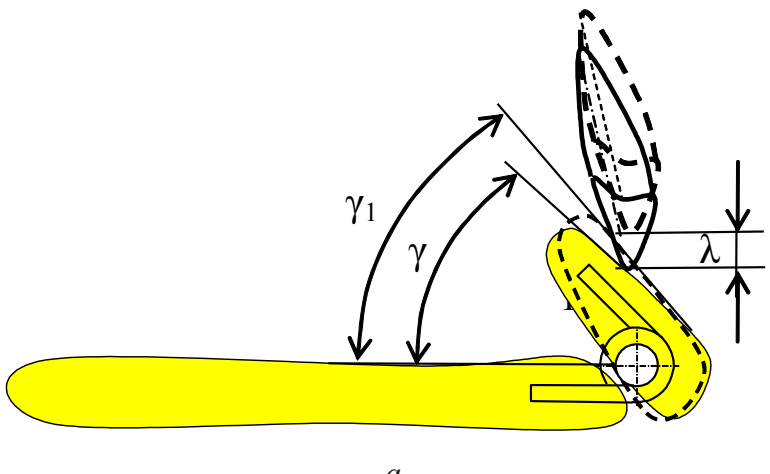

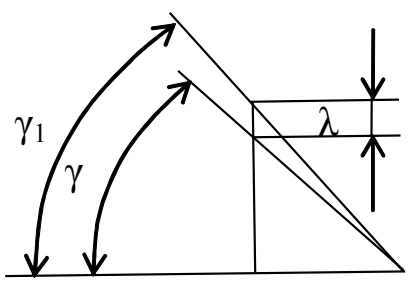

Fig. 5. Turning of the ramp during the vertical movements of the mandible. $a$-correlation of teeth related to the ramp; $b$ - changing of angle $\gamma$ during vertical displacement

When $\gamma_{\mathrm{C}}=45^{\circ}, \lambda=4$ and $\mathrm{l}=5 \mathrm{~mm}$, appliances ramp angle changes by an amount $\left(\gamma-\gamma_{\mathrm{C}}\right)=20$.

With the change of the movable ramp inclination angle $\gamma$, changes also moment 1 of force $\mathrm{R}_{2}$ :

$$
\mathrm{l}=\mathrm{l}_{\mathrm{C}} \cos \gamma_{\mathrm{C}} / \cos \gamma \text {. }
$$

Solving the system of equations (7)-(11) with in relation to orthodontic forces, we get its dependence on the vertical movement of the lower jaw $R_{2}(\lambda)$.

During the treatment of Class III malocclusion also takes place an extension of the frontal part of the upper dental arch (Fig. 6, a). After displacement by a distance $\lambda_{1}($ Fig. 6, b), the angle of the movable ramp becomes:

$$
\gamma=\operatorname{arctg}\left[\left(1_{C} \sin \gamma_{C}\right) /\left(1_{C} \cos \gamma_{C}-\lambda_{1}\right)\right] .
$$


If $\gamma=45^{\circ}, \lambda_{1}=1$ and $\mathrm{l}=5 \mathrm{~mm}$, twist is of the inclined plane $\left(\gamma-\gamma_{\mathrm{C}}\right)=9$.

The displacement also results in a decrease in 1 arm moment of strength $\mathrm{R}_{2}$ :

$$
\mathrm{l}_{\mathrm{C}} \mathrm{l}_{\mathrm{C}} \sin \gamma_{\mathrm{C}} / \sin \gamma
$$
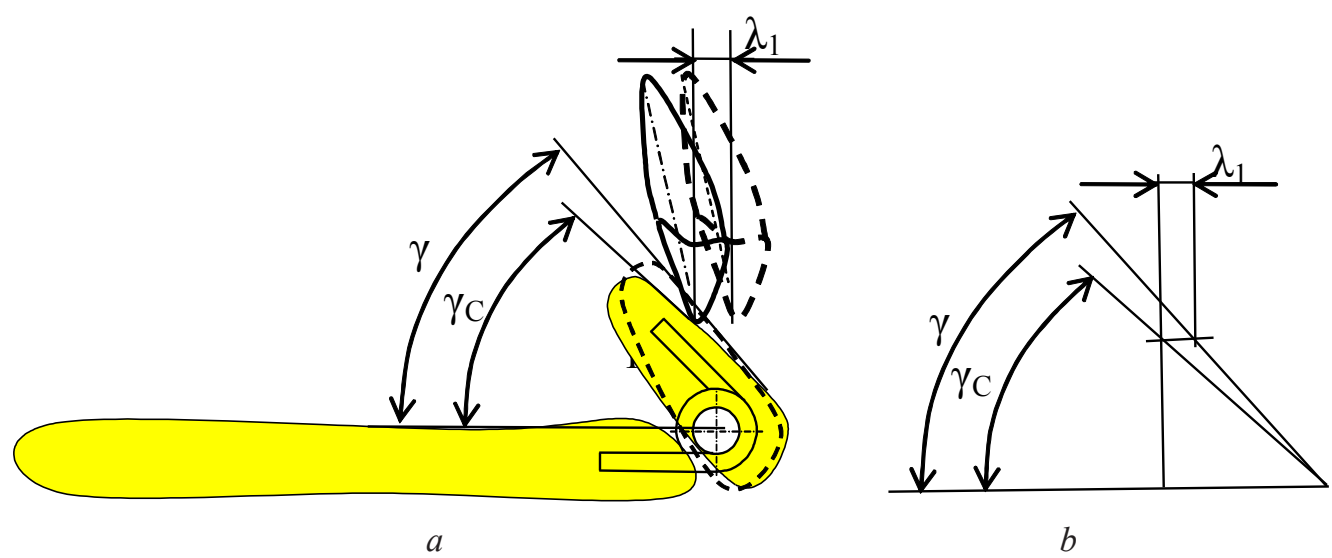

Fig. 6. Turning of ramp during the displacement of the mandible along the occlusal plane. $a$-correlation of teeth related to the ramp in occlusal plane; $b$ - changing of angle $\gamma$ during sagittal displacement

Solving the system of equations (7)-(9), (12), (13) in relation to orthodontic force we get $\mathrm{R}_{2}$ dependence on $\lambda_{1}$ distance.

In the case of less rigid spring $(\mathrm{n}=5, \mathrm{~d}=0,5 \mathrm{~mm})$ during a displacement of dental arches for the $\lambda_{1}=1 \mathrm{~mm}$ small local growth orthodontic effort occurs, which is achieved by reducing orthodontic force arm.

\section{Results}

Analysis of the dentoalveolar apparatus with functionally-directing appliance with a movable ramp and passive torsion springs showed that their distribution in moment of the maximum forces is the same as both with the presence and in case of their absence. At muscles rest condition the appliance with passive spring acts similarly to the fixed ramp, without creating any additional forces. However, the presence of the elastic hinge between the ramp and the basis of the device changes its stiffness, i. e., ability to deformation under the influence of mechanical stress.

By using springs which tend to increase the angle $\beta$ during the resting of muscles, i. e. change the angle $(\alpha-\beta)$, a movable ramp will create additional effect of mechanical factors affecting anterior teeth not only when swallowing, but also at rest.

Unwinding curls of spring creates contact (force) between the appliance and the frontal teeth at physiological rest, and compensates the angle $(\alpha-\beta)$ in the process of moving teeth. Appliance with movable ramp is able to maintain a longer time predetermined angle $(\alpha-\beta)$ as compared with stationary appliances. The exact time interval of changes of the axial inclination of teeth $\alpha$ is an individual parameter of each patient and depends on the duration of orthodontic appliance usage, as well as the characteristics of the structure and the formation of dentoalveolar apparatus.

Orthodontic force is more stable in the case of using the springs made from wire of smaller diameter and with a greater number of curves.

\section{Discussion}

Studies have shown that orthodontic force depends on the angle of the appliance ramp, the parameters of the facial skeleton (the distance from the point that corresponds to the 
center of the temporomandibular joint head to the contact point of the central incisors), the angle of axial inclination of the anterior teeth, the coefficient of friction between the ramp and the patient's teeth.

By setting different angles of inclination, the position of the frontal teeth and the alveolar crest can be changed from the translational motion in the direction of the tooth axis to the translational and rotational - in the vestibular direction.

The presence of elastic hinge between the appliances base and the ramp allows maintain a stable level of orthodontic forces in the course of treatment, when the effect of an increasing in the saggital distance between the upper and lower teeth is present.

\section{Conclusions}

1. Minimum orthodontic force will occur in the case when the angle between the ramp and a line connecting a point that represents the center of the temporomandibular joint articular head, and the contact point of incisors will be equal to the arctangent of the coefficient of friction between the patient's teeth and the ramp.

2. Most preferred angle between the ramp and the axis of the upper frontal teeth is about $30^{\circ}$.

3. The movable ramp with active springs acts on the teeth not only during the act of swallowing, but in a state of physiological rest.

4. The greatest influence on the rigidity of the orthodontic appliance has a diameter of the spring wire - spring rate increases in proportion to the fourth power of the diameter of the wire.

5. In order to reduce the rigidity of orthodontic appliance is necessary to increase the diameter of the turns of the springs and their number.

6. The usage of less rigid appliances with movable ramp stabilizes orthodontic force and accelerates the process of malocclusion treatment.

\section{References}

[1] Flis, P. (2007). Ortodontiia. Vinnytsia: Nova knyha, 312.

[2] Flis, P., Leonenko, G., Filonenko, V., Doroshenko, N. (2015). Orthodontics. Dentognathic Anomalies and Deformations: textbook. Kyiv: AUS Medicine Publishing, 176.

[3] Flis, P., Vlasenko, A., Chupina, A. (2013). Tehnologija vigotovlennja ortodontichnih ta ortopedichnih konstrukcij u ditjachomu vici: Pidruchnik. Kyiv: VSV "Medicina”, 256.

[4] Kuroedova, V., Zhdan, V., Halych, L. (2011). Atlas ortodontycheskykh apparatov. Poltava: Dyvosvit, 154.

[5] Rakosi, T., Graber, T., Dragomireckaja, M. (2012). Zuboal'veoljarnoe i cheljustno-licevoe ortodonticheskoe lechenie. Lviv: GalDent, 397.

[6] Kalvelis, D. (1961). Biomorfologicheskie osnovy ortodonticheskogo lechenija. Riga, 220.

[7] Malanchuk, V. O., Borysenko, A. V., Khomenko, L. O., Nespriadko, V. P. (2012). Basis of dentistry. Vinnytsia: Nova Knyha, 616.

[8] Henderson, J., Natochina, J. (2013). Patofiziologija organov pishhevarenija. Moscow: Binom, 272.

[9] Flis, P., Filonenko, V., Doroshenko, N. (2015). UA. Patent № 99388 (51)PK A 61C 7/00, 5. Ortodontychnyi aparat P.S. Flisa, V.V. Filonenka, N.M. Doroshenko z rukhomoiu pokhyloiu ploshchynoiu dlia likuvannia sahitalnykh ta transverzalnykh anomalii prykusu. u201502553. zajavl. 23.03.2015; opubl. 25.05.2015; bjul. № 10.

[10] Flis, P., Filonenko, V., Doroshenko, N. (2015). Perspektyvy vykorystannia rukhomykh pokhylykh ploshchyn $\mathrm{v}$ znimnykh ortodontychnykh aparatakh dlia likuvannia sahitalnykh ta transverzalnykh anomalii okliuzii prykusu. Materialy VI Konhresu Pivdenno-Skhidnoho Yevropeiskoho medychnoho forumu ta XIV z'izdu VULT. Odesa, 372-373.

[11] Flis, P., Filonenko, V., Doroshenko, N. (2016). Vykorystannia ortodontychnym aparativ z rukhomymy pokhylymy ploshchynamy dlia likuvannia mezialnoho prykusu. Ukrainska ortodontychna shkola: vchora, sohodni, zavtra. Kyiv, 61-63. 
[12] Chujko, A., Shinchukovskij, I. (2010). Biomekhanika v stomatologii. Kharkiv, 468.

[13] Nespriadko, V. P., Chernykh, N. S., Hryhorenko, O. Ia. (2014). Matematicheskoe modelirovanie chastichnogo s"yomnogo protezirovaniya s ispol'zovaniem zamkovykh ustrojstv. Molodoj uchenyj, 3 (62), 215-222.

[14] Osnach, R. G., Bida, O. V. (2014). Matematicheskoe obosnovanie primeneniya ortodonticheskogo metoda zameshheniya defekta zubnogo ryada. Sovremennaya ortodontiya, 2, 36-38.

[15] Likhota, K. N. (2015). Mekhaniko-matematicheskoe modelirovanie lecheniya sagittal'nykh zubochelyustnykh anomalij s pomoshh'yu ehlastopozitsionerov. Sovremennaya ortodontiya, 3 (41), 49-51.

[16] Hryhorenko, Ia. M., Hryhorenko, O. Ia., Nespriadko, V. P., Tormakhov, N. N., Zakurko, S. V. (2015). O nesushhej sposobnosti klammerov s"emnykh ctomatologicheskikh protezov iz termoplastov. Dopovidi Natsionalnoi Akademii nauk Ukrainy, 12, 111-118.

[17] Storozhenko, K. V., Flis, P. S., Tormakhov, N. N. (2015). Ortodonticheskie sily v apparatakh dlya lecheniya mezial'nogo prikusa. Ukrainskyi stomatolohichnyi zhurnal, 6, 52-55.

[18] Hryhorenko, Ia. M., Hryhorenko, O. Ia., Shpak, D. Iu., Flis, P. S. (2014). Metodika lecheniya gnaticheskoj formy mezial'nogo prikusa. Dopovidi Natsionalnoi Akademii nauk Ukrainy, 6, 160-166.

[19] Hryhorenko, Ia. M., Hryhorenko, O. Ia., Nespriadko, V. P., Tykhonov, D. A. (2013). Metodika opredeleniya opornykh reaktsij pri chastichnom s"yomnom protezirovanii v stomatologi. Dopovidi Natsionalnoi Akademii nauk Ukrainy, 1, 171-176.

[20] Hryhorenko, Ia. M., Hryhorenko, O. Ia., Nespriadko, V. P., Tormakhov, N. N., Tykhonov, D. A. (2012). Opredelenie opornykh reaktsij chastichnykh s"emnykh protezov. Visnyk problem biolohii i medytsyny, 3, 136-139.

[21] Yablonskij, A., Nikiforova, V. (2011). Kurs teoreticheskoj mekhaniki. Moscow: KnoRus, 608.

[22] Anur'ev, V. I. (2006). Spravochnik konstruktora-mashinostroitelya. Vol. 1. Moscow: Mashinostroeni, 928.

[23] Charles, J., Kwangchul, Ch. (2015). The Biomechanical Foundation of Clinical Orthodontics. Quintessence Pub Co, 608. 